\title{
The first register of the weed fern Pteris cretica var. laeta (Pteridaceae) in central Argentina
}

\author{
Primer registro del helecho maleza Pteris cretica var. laeta \\ (Pteridaceae) en Argentina central
}

\author{
Arana, Marcelo D. ; Evangelina Natale; Gonzalo Martínez; \\ Antonia J. Oggero \\ Orientación Plantas vasculares, Departamento de Ciencias Naturales, Facultad de Ciencias Exactas, \\ Físico-Químicas y Naturales, Instituto ICBIA (UNRC-CONICET), Universidad Nacional de Río Cuarto, \\ Ruta 36 km 601, X5804ZAB Río Cuarto, Córdoba, Argentina. \\ ORCID: \\ Marcelo Arana: https://orcid.org/0000-0001-7921-6186 \\ Evangelina Natale: https://orcid.org/0000-0001-6056-0745 \\ Gonzalo Martínez: https://orcid.org/0000-0002-0846-8033 \\ Antonia Oggero: https://orcid.org/0000-0002-5354-4779 \\ * Corresponding author: Marcelo Arana, marana@exa.unrc.edu.ar.
}

\section{RESUMEN}

Se registra por primera vez a Pteris cretica L. var. laeta en la provincia biogeográfica Comechingones, en Argentina central. Este constituye el primer registro de P. cretica en Argentina central y de $P$. cretica var. laeta para el país. Hasta el momento Pteris cretica ha sido registrado, en América, en Norteamérica (Florida), América central y Sudamérica en los biomas neotropicales de Perú, Chile, Brasil, Paraguay, Uruguay y el norte de Argentina, establecido en la provincia biogeográfica de las Yungas, así como ruderal en Buenos Aires. Se provee una descripción actualizada, además de fotografías, diferencias con $P$. cretica var. cretica y características del nuevo hábitat para la especie y variedad.

Palabras clave - Especies exóticas; Polypodiopsida; Provincia Comechingones; Pteridoideae; Sierras Pampeanas centrales.

Ref. bibliográfica: Arana, M. D.; Natale, E.; Martínez, G.; Oggero, A. J. 2020. "The first register of the weed fern Pteris cretica var. laeta (Pteridaceae) in central Argentina". Lilloa 57 (2): 99-109. Fundación Miguel Lillo, Tucumán, Argentina. D.O.I.: doi.org/10.30550/j.lil/2020.57.2/2

> Recibido: 19 junio 2020 - Aceptado: 28 agosto 2020

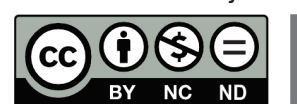




\begin{abstract}
Pteris cretica L. var. laeta is recorded for the first time in the Comechingones biogeographic province in central Argentina. This is the first record of $P$. cretica in central Argentina, and P. cretica var. laeta for the country. Until now Pteris cretica has only been known to occur, in America, in North America (Florida), Central America and South America in Neotropical biomes from Peru, Chile, Brazil, Paraguay, Uruguay and northern Argentina as established in the Yungas biogeographic province, and as ruderal in Buenos Aires. An updated description is provided, along with pictures, differences with $P$. cretica var. cretica, and characteristic of the novel habitat of the species and variety.
\end{abstract}

Keywords - Central Pampean Ranges; Comechingones province; Exotic species; Polypodiopsida; Pteridoideae.

\title{
INTRODUCTION
}

The Pteridaceae E.D.M. Kirchn. comprises five subfamilies with over 53 genera and more than 1,200 species that represent approximately $10 \%$ of extant leptosporangiate fern diversity (Christenhusz, Zhang \& Schneider, 2011; Pteridophyte Phylogeny Group [PPG] I, 2016). This family also accommodates plants having an unusually broad range of ecological niches, including terrestrial, epiphytic, rupestral (growing on or among rocks), and aquatic habitats (Schuettpelz, Schneider, Huiet, Windham \& Pryer, 2007). The cosmopolitan fern genus Pteris L. (subfamily Pteridoideae, Pteridaceae; PPG I, 2016) is one of the most diverse, including approximately 250 species that inhabit temperate, tropical and subtropical regions of all continents (except Antarctica) from Australia, New Zealand, South Africa and South America northward to Japan and North America. Pteris is characterized by having rhizome erect or ascending (rarely long-creeping), sporangia arranged continuously along most of the length of the pinnae from commissural veins, pinnae entire or pectinately divided into segments, sometimes asymmetrical, and brown spores with an equatorial flange (Cha, Rouhan, Amoroso \& Chiou, 2014; Zhang et al., 2014). The species grow from open slopes to dense forests and from acid soils to limestone rock; about 60 taxa develop in the tropical Americas (Tryon \& Tryon 1982, Tryon, Tryon \& Kramer, 1990; Liao, Ding, Wu, Prado \& Gilbert, 2013; Chao et al., 2014).

Some species, as Pteris cretica L., P. longifolia L., P. multifida Poir., P. tremula R. Br., $P$. tripartita $\mathrm{Sw}$. and $P$. vittata $\mathrm{L}$. are reported as invasive weeds in many parts of the world, being increasingly found in both, natural and urban areas in several countries possibly as a result of climate change (Wilkins \& Salter, 2003; Mac Donald, Sellers, Langeland, Duperron-Bond \& Ketterer-Guest, 2008; Robinson, Sheffield \& Sharpe, 2010; Silva Junior, Fernandes \& Ferreira, 2018). Pteris tremula, originally distributed in the Australasian South Pacific, was recently cited as established in Argentina, in diverse environments like marginal forest, Espinal forests, flooded scrublands and also disturbed habitats (Arana, Berrueta, Luna \& Giudice, 2020). 
Pteris cretica, P. multifida and P. vittata are species originated in Asia (China) or Europe and have been cited as established in many regions of America since long time ago (e.g. Capurro, 1969; de la Sota, 1977; Prado \& Windisch, 2000; Martinez, 2011; Mazumdar \& Arana, 2016). Among them, Pteris cretica commonly known as "Cretan brake", "Cretan fern" or "ribbon brake" is a fern that has been widely distributed as an ornamental species; and the potential economic and environmental impacts of the invasion of this species in novel habitats are not well known. According to Global Invasive Species Database [GISD] (2015), on the British Isles this species is considered a threat more so for its progressive radial expansion in range that has been apparent since 1930 rather than any potential ecological and economic impacts. In the ecologically fragile limestone grottoes of Florida (United States), P. cretica can be problematic to rare native species if facilitated by shady, humid conditions.

From the last 10 years on, the Argentinian flora has been continuously enlarged with new alien plant species, which represents a serious problem particularly in the natural environments that are threatened by habitat loss and fragmentation (Gavier \& Bucher 2004; Arana \& Oggero 2009; Hoyos et al., 2010; Oggero \& Arana 2012). Human alterations of natural habitats are probably irreversibly changing these environments into novel ecosystems through severe modifications both, in the abiotic conditions and the biotic composition (Hobbs, Higgs \& Harris, 2009). Organisms sometimes cause harm when they are relocated from the ecosystem of their evolutionary origin to new ecosystems; however, the greatest invasive alien species problems worldwide occur when non-native species are brought into novel ecosystems either intentionally or unintentionally. The globalization of trade, travel, and transport is greatly increasing the number and diversity of invasive alien species being moved around the world, as well as the rate at which they are moving. The presence of exotic species in an ecosystem can produce not only profound changes in community structure, but also in ecosystem functioning (Godoy, Castro-Díez, van Logtestijn, Cornelissen \& Valladares, 2010) and usually led to a native diversity impoverishment. Some of these alien species can become invasive, threatening natural and agricultural ecosystems, causing damage to the economy and human health (McNeely 2001; Gavier-Pizarro, Radeloff, Stewart, Huebner \& Keuler, 2010). In addition, non-native plants are often given low priority by collectors, therefore, leading to gaps in our knowledge (Baldwin et al., 2012), specially the herbaceous plants. Accordingly, without continuing documentation needed to make informed decisions (i.e., collecting specimens, monitoring occurrences, and maintaining professionally curated herbaria) some established species may have been overlooked and lacking current distributional data. Reporting and documenting those newly alien species arrived in Argentinian flora, and specially monitoring the spreading of those previously reported can be useful tools in establishing measures in order to eradicate them before becoming invasive and harmful.

During fieldworks from projects that investigates the diversity and distribution of ferns in Southern Cone (http://conosur.floraargentina.edu.ar), Argentina (www. floraargentina.edu.ar) and specifically the Flora of Córdoba province; at least three populations of Pteris cretica were registered growing naturally in central Argentina. Thus, arises as the aim of this work to extend the distribution of this species to 
Comechingones biogeographic province (Arana et al., 2017), as established in natural habitats of in Pampean Highlands of Argentina.

\section{METHODS}

Field campaigns in the provinces of Córdoba and San Luis led to the discovery of at least three populations of Pteris cretica growing terrestrially, not previously known from central Argentina. The voucher specimens were deposited in RCVC. Specialized literature was used to confirm identity of the species and determine its geographic distribution, particularly in Argentina (Christensen \& Tardieu, 1937; Shieh, 1966; Walker, 1970; Nauman, 1993; de la Sota et al., 2001; Rumsey \& Crouch, 2008; Zhang et al., 2013; Martinez \& Prado 2016). Additional data were obtained from speciesLink (http://splink.cria.org.br/), Tropicos (http://www.tropicos.org/), Catalogue of Life (http://www.catalogueoflife.org/), and Flora del Cono Sur (http://www2.darwin. edu.ar/Proyectos/FloraArgentina/) databases. The collections and databases from the following herbaria: BA (Bernardino Rivadavia Museum, Buenos Aires, Argentina), CORD (Botanical Museum, National University of Córdoba, Córdoba, Argentina), CTES (Instituto de Botánica del Nordeste, Corrientes, Argentina), JUA (National University of Jujuy, Jujuy, Argentina), LIL (Fundación Miguel Lillo, Tucumán, Argentina), LP (National University of La Plata, Buenos Aires, Argentina), MCNS (National University of Salta, Salta, Argentina), RCVC (Natural Sciences Department, National University of Río Cuarto, Córdoba, Argentina), and SI (Instituto Darwinion, Buenos Aires, Argentina) were consulted in order to obtain the complete distribution of Pteris cretica in Argentina.

\section{RESULTS AND DISCUSSION}

Pteris cretica Linnaeus var. laeta (Wallich ex Ettingshausen) C. Christensen \& Tardieu, Notul. Syst. (Paris) 6: 137. 1937. Pteris cretica subsp. laeta (Wall. ex Ettingsh.) Fraser-Jenk., Taxon. Revis. Indian Subcontinental Pteridophytes, 100. 2008. Pteris laeta Wallich ex Ettingshausen, Farnkr. Jetztw. 96. 1864. Type: Nepal, 1820, N. Wallich cat. no. 95 (NY, LE, K, PH).

Perennial herbs of near $45 \mathrm{~cm}$ tall. Rhizome creeping or ascending, apex with blackbrown scales. Fronds clustered, dimorphic or subdimorphic; stipe straw-colored at the apex, brown to dark brown to the base up to the middle, scabrous, $10-45 \mathrm{~cm}$. Sterile fronds: stipe shorter, glabrous; lamina 1-pinnate or sometimes digitate, ovate in outline, $10-20$ [-30] $\times 6-10$ [-30] cm; pinnae ( 2 or) 3-5 pairs, often opposite, decumbent, basal pinnae each with 2 (or 3 ) pinnules, shortly stalked, upper pinnae narrowly lanceolate or lanceolate, sometimes with basiscopic lobe, 10-15 (-20) $\times$ $1-1.5(-2.5) \mathrm{cm}$, sessile, base broadly cuneate, margin very undulate, white cartilaginous and irregularly serrate, apex acuminate. Fertile fronds longer than sterile ones: stipe 30-45 cm; pinnae 3-5 (-8) pairs, opposite or upper alternate, decumbent, basal 
pinnae with ( 1 or) 2 (or 3) pinnules, shortly stalked (2-4 $\mathrm{mm}$ ); upper pinnae linear, sometimes with lateral pinnule, $12-25 \times 0.5-1.2 \mathrm{~cm}$, sessile, base broadly cuneate, terminal pinna 3-lobed, base decurrent. Lamina green or gray-green, papery when dried, glabrous; midvein abaxially straw-colored, glabrous; veins conspicuous on both surfaces, distant, oblique, simple or forked at base. The spores are trilete, triangular in polar view, with convex sides and rounded corners; hemispheric-convex in equatorial view, proximally verrucate and distally rugate with numerous small processes, isolated or fused at the distal pole.

According to Martinez (2010), gametophytes of the species P. cretica are photosynthetic, cordiform, bisexual and protandric, and also there are male gametophytes. Antheridia are ovoid, archegonia necks have 4 rows of 4 cells each.

\section{Selected specimens revised}

ARGENTINA. Prov. Córdoba, Dpto. Río Cuarto, Alpa Corral, road to "Las Guindas”, 32³6'43.1313”S, 6443’40.40”O, 30-X-2015, Arana s.n. (RCVC); 20-XI-2018, M. Arana s.n. (RCVC). Dpto. Calamuchita, arroyo tributario río de los sauces, 32³7’00.84"S, 6443'43.90"O, 1040 m, 13-XI-2017, M. Arana E A. Oggero s.n. (RCVC); ibidem, 32³5'44.13"S, 64²'49.93”O, 1005 m, 13-XI-2017, M. Arana $\mathcal{E}$ A. Oggero s.n. (RCVC).

Two varieties are usually recognized (Zhang et al., 2013), all plants from central Argentina responds to Pteris cretica var. laeta (Wallich ex Ettingshausen) C. Christensen \& Tardieu. It differs from Pteris cretica var. cretica by the stipe often brown, surface scabrous; sterile pinna margins undulate, teeth longer and at rather irregular angles (vs. stipe straw-colored with smooth surface; sterile margins flat and straight, teeth small and regularly angled). Also, Pteris cretica var. laeta is taller and stronger than var. cretica. It is an apomictic triploid (Zhang et al., 2013).

In the species Pteris cretica, numerous cultivars are known, and the 'crested pinnae' forms, have been popular for decades. Cresting usually refers to fronds, pinnae, or segments having forked tips. In cultivated varieties, 'cresting' seems to be a permanent characteristic, which breeds true in the spore progeny (Hoshizaki \& Moran, 2001).

\section{Distribution}

The native range of this species is obscure, but seems to be originally paleotropical distribution. As a whole, Pteris cretica occurs widely throughout the tropics and subtropics. It is frequently cultivated and escapes, obscuring the natural distribution (Zhang et al., 2013). In America is found from USA (South Carolina to Florida), Central America (Mexico, Costa Rica, Honduras, Jamaica, Panama and Antillas), Neotropical biomes of Peru, Chile, Brazil, Paraguay, Uruguay and Argentina. In the last country is established in the provinces of Jujuy, Salta, Tucumán (Martínez 


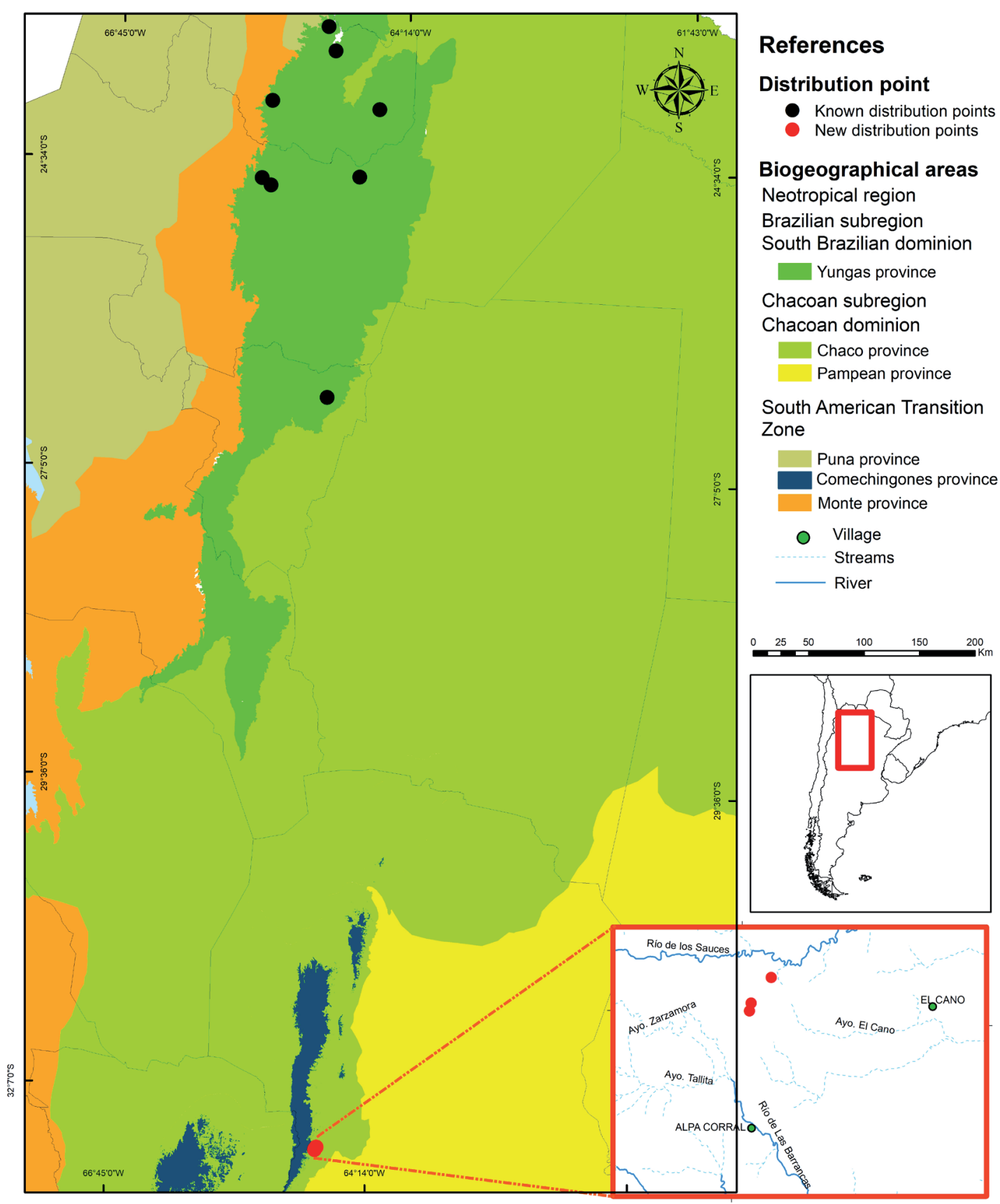

Fig. 1. Geographical distribution of Pteris cretica in Argentina (black dots) and the new records of Pteris cretica var. laeta in Comechingones biogeographic province (red dots).

\& Prado, 2016) inhabiting the natural environments of Yungas, from 400 to 2500 $\mathrm{m}$ a.s.l.; and now Córdoba (Figure 1). The specimens studied here were collected at 1000-1040 m a.s.l., inhabiting shady stream banks in high altitude grasslands. These populations consisted of many individuals grouped and scattered in shadow humid places accompanied by specimens of the predominant Cortaderia selloana (Schult. \& Schult. f.) Asch. \& Graebn. subsp. selloana, Melica macra Nees, the macrophytes Hydrocotyle bonariensis Lam., Hydrocotyle ranunculoides L. f., the lycophytes Selaginella microphylla (Kunth) Spring and Selaginella sellowii Hieron., and the ferns Cheilanthes 
buchtienii (Rosenst.) R.M. Tryon, Blechnum auriculatum Cav., Amauropelta argentina (Hieron.) Salino \& T.E. Almeida and Adiantum raddianum C. Presl native species (Figure 2). The species Pteris cretica is also found as ruderal in modified, urban environments of Buenos Aires province. According to Yañez, Gutierrez \& Ponce (2020), it is a very common species in disturbed and ruderal environments, such as roadsides or humid walls. It is registered as an apogamic species (Martínez, 2010) and, probably, this characteristic is related to the almost cosmopolitan distribution of the species and the facility to colonize new environments (Yañez et al., 2020). In Argentina the species is also mentioned in Malvinas archipelago (Martínez, 2011;
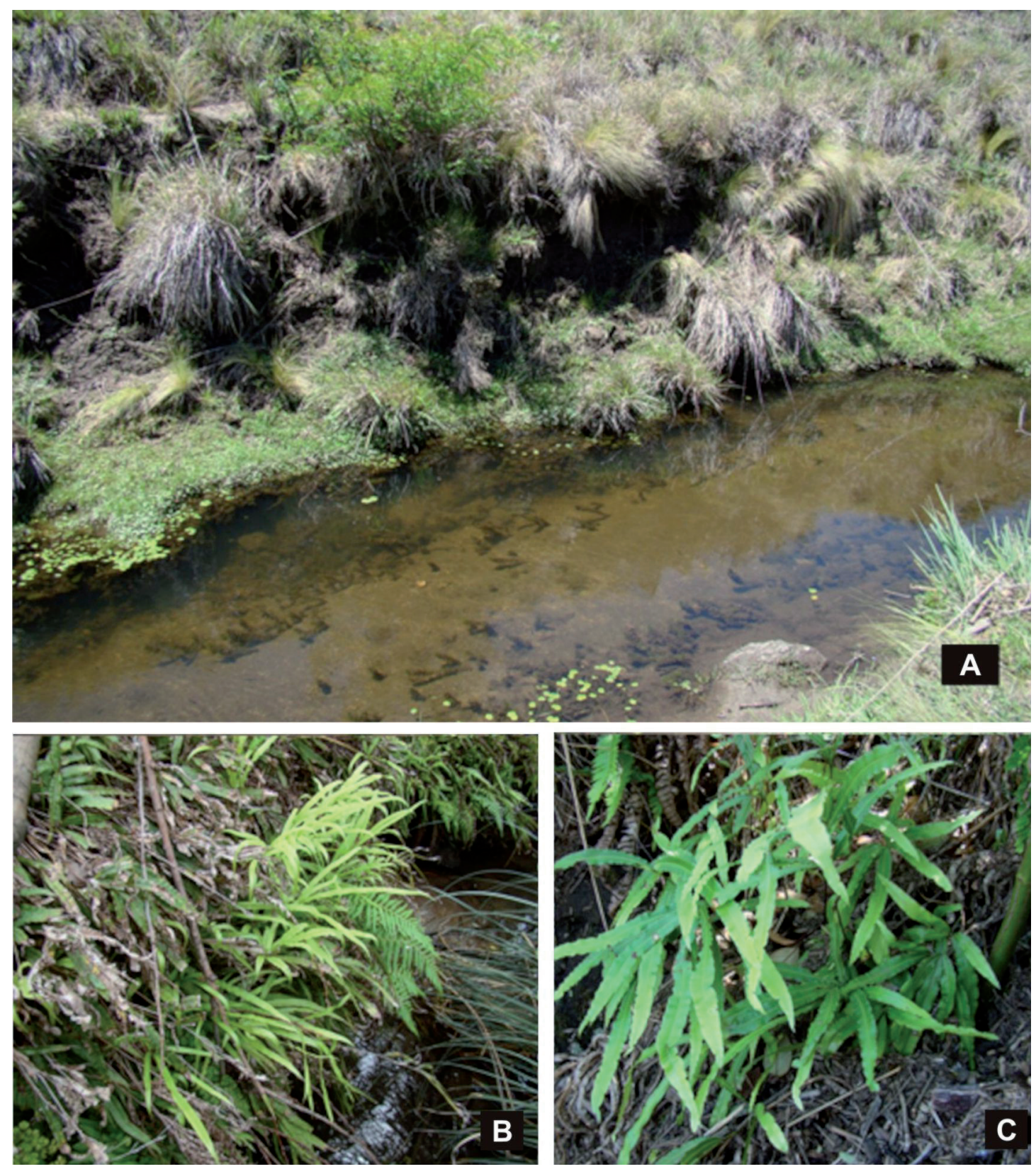

Fig. 2. Pteris cretica populations in the Comechingones biogeographic province. A) Habitat of Pteris cretica. B) Population of Pteris cretica var. laeta occupying the habitats of native ferns as Adiantum raddianum and Amauropelta argentina. C) Fertile specimen of Pteris cretica var. laeta. 
Martínez \& Prado 2016, Yañez et al., 2020), but without mentioning specimens that document the presence of the species in the islands. As we were not able to find specimens from Malvinas, we avoid to extend the range of the distribution in Malvinas islands of the species Pteris cretica.

In central Argentina (Córdoba, San Luis and La Pampa political provinces), with the addition of the new records, the genus Pteris is confirmed with two species, both exotic: Pteris vittata L. and Pteris cretica L. var. laeta. Instead of the populations of Pteris vittata, which are found in anthropogenic, urban habitats (Arana, Ponce \& Vischi, 2004; Arana \& Bianco, 2011), the registered populations of Pteris cretica var. laeta were found inhabiting natural environments of Comechingones biogeographic province. These habitats are characterised by altitude grasslands with predominance of genera Festuca and Nassella and woodlands with predominance of Polylepis australis Bitter ('tabaquillo') and Maytenus boaria Molina ('maitén') in mountainous regions of central Argentina, between $29^{\circ}$ and $33^{\circ} \mathrm{S}$, in Córdoba and San Luis provinces, at an altitude above $1000 \mathrm{~m}$ (Martínez, Arana, Oggero \& Natale, 2017). The populations of Pteris cretica var. laeta are always found in the banks of watercourses like streams with dark, silty soil with abundant organic matter. This is the first record of $P$. cretica in central Argentina, and P. cretica var. laeta for the country. Some of the previous mentions of the ruderal Pteris cretica for Buenos Aires province in Argentina, based on specimens with pinnules often with conspicuous pale central band, corresponds to Pteris nipponica W. C. Shieh (Guerrero, 2017), Plants of this species were originally treated as a cultivar of Pteris cretica (Zhang et al., 2013), or classically known under the name Pteris cretica var. albolineata Hook. See discussions in Fraser-Jenkins (2008), Knapp (2011) and Zhang et al. (2013) regarding the close relationship between $P$. nipponica and the $P$. cretica group. The Pteris cretica species complex (Tryon \& Tryon, 1982), is represented with nine species in Central and South America, five of them are established: Pteris cretica L., P. ensiformis Burm. f., P. vittata L., P. multifida Poir. and P. nipponica Shieh. Among the species belong to this complex, Pteris cretica is mentioned as invasive in many places, probably escaped from cultivation (GISD, 2015). Given that biological diversity is dynamic, continually evolving and changing in response to biotic and abiotic fluctuations and other environmental pressures, it is necessary to record in time and space its status quo and, subsequently, monitor that status quo in order to identify changes and assess their impacts. Such impacts may require intervention or mitigation measures to safeguard the future conservation, including sustainable use, of native biological diversity, as probably is the case of the alien species of Pteris in central Argentina.

\section{ACKNOWLEDGEMENTS}

The authors are very thankful to Dr. Monica Ponce (SI) for the critical reading of an early version of the manuscript and her suggestions. We want to acknowledge to the revisors for their helpful comments. 


\section{REFERENCES}

Arana, M. D., Ponce, M. \& Vischi, N. (2004). Sinopsis de los helechos y grupos relacionados (Pteridophyta) de la provincia de Córdoba, Argentina. Boletín de la Sociedad Argentina de Botánica 39 (1-2): 89-114.

Arana, M. D., \& Oggero, A. J. (2009). Zanthoxylum armatum (Rutaceae), su presencia en Argentina. Darwiniana 47: 335-338.

Arana, M. D. \& Bianco, A. (2011). Helechos y licófitas del centro de la Argentina. Universidad Nacional de Río Cuarto, Río Cuarto, Córdoba, Argentina.

Arana, M. D., Martínez, G. A., Oggero, A. J., Natale, E. S. \& Morrone, J. J. (2017). Map and shapefile of the biogeographic provinces of Argentina. Zootaxa 4341 (3): 420-422. doi:10.11646/zootaxa.4341.3.6.

Arana, M. D., Berrueta, P., Luna, M. L. \& Giudice, G. E. (2020). Pteris tremula (Polypodiopsida: Pteridaceae) a naturalized species in Argentina. American Fern Fournal 110 (2): 66-69. doi: https://doi.org/10.1640/0002-8444-110.2.66.

Baldwin, B.G., Goldman, D. H., Keil, D. J., Patterson, R., Rosatti, T. J. \& Wilken, D. H. (2012). General conventions. The Fepson manual: Vascular plants of California, 2nd ed. University of California Press, Berkeley, U.S.A.

Capurro, R. H. (1969). División Pteridophyta. En: A. L. Cabrera (Ed.), Flora de la Provincia de Buenos Aires. Colección Cientifica del Instituto Nacional de Tecnología Agropecuaria 4: 123-146.

Chao, Y. S., Rouhan, G., Amoroso, V. B. \& Chiou, W. L. (2014). Molecular phylogeny and biogeography of the fern genus Pteris (Pteridaceae). Annals of Botany 114: 109-124.

Christenhusz, M., Zhang, X. \& Schneider, H. (2011). A linear sequence of extant families and genera of lycophytes and ferns. Phytotaxa 9: 7-54.

Christensen, C. F. A. \& Tardieu, M. L. (1937). Les fougères d'Indochine. XI Pterideae. Notulae Systematicae 6: 135-149.

de la Sota, E. R. (1977). Pteridofitas. En: Cabrera, A.L. (Ed.), Flora de la Provincia de Jujuy. Colección Cientifica del Instituto Nacional de Tecnología Agropecuaria 13: 1-275.

de la Sota, E. R., Martínez, O. G., Ponce, M. M., Giudice, G. E. \& Michelena, G. I. (2001). Pteridaceae. En: Novara, L. (Ed.), Flora del Valle de Lerma. Aportes Botánicos de Salta-Serie Flora 6 (9): 1-59.

Fraser-Jenkins, C. R. (2008). Taxonomic revision of three hundred Indian subcontinental pteridophytes with a revised census-list: a new picture of fern-taxonomy and nomenclature in the Indian subcontinent. India: Bishen Singh Mahendra Pal Singh.

Gavier, G. I. \& Bucher, E. H. (2004). Deforestación de las Sierras Chicas de Córdoba (Argentina) en el periodo 1970-1997. Academia Nacional de Ciencias, Córdoba.

Gavier-Pizarro, G. I., Radeloff, V. C., Stewart, S. I., Huebner, C. D. \& Keuler, N. S. (2010). Housing is positively associated with invasive exotic plant species richness in New England, USA. Ecological Applications 20 (7): 1913-1925. 
GISD (Global Invasive Species Database) (2015). Species profile Pteris cretica. Available from: http://www.iucngisd.org/gisd/species.php?sc $=1672$.

Godoy, O., Castro-Díez, P., van Logtestijn, S. P., Cornelissen, J. H. C. \& Valladares, F. (2010). Leaf litter traits of invasive species slow down decomposition compared to Spanish natives: a broad phylogenetic comparison. Oecologia 162: 781-790.

Guerrero, E. L. (2017). Pteris nipponica (Pteridaceae), a new record for the exotic flora of Buenos Aires, Argentina. Bonplandia 26 (2): 137-142.

Hobbs, R. J., Higgs, E. \& Harris, J. A. (2009). Novel ecosystems: implications for conservation and restoration. Trends in Ecology E Evolution 24: 599-605.

Hoshizaki, B. J. \& Moran, R. C. (2001). Fern grower's manual, revised and expanded ed. Portland, Oregon, USA: Timber Press.

Hoyos, L. E., Gavier-Pizarro, G. I., Kuemmerle, T., Bucher, E. H., Radeloff, V. C. \& Tecco, P. A. (2010). Invasion of glossy privet (Ligustrum lucidum) and native forest loss in the Sierras Chicas of Córdoba Argentina. Biological Invasions 12: 3261-3275.

Knapp, R. (2011). Ferns and Fern Allies of Taiwan. Taiwan: KBCC Press.

Liao, W. B., Ding, M. Y., Wu, Z. H., Prado, J. \& Gilbert, M. G. (2013). Pteris. Flora of China 2-3: 181-211.

MacDonald, G., Sellers., B., Langeland, K., Duperron-Bond., T. \& Ketterer-Guest, E. (2008). Chinese Ladder Brake Fern (Pteris vittata): Invasive Species Management Plans for Florida. Gainesville, FL, USA: Center for Aquatic and Invasive Plants, University of Florida.

Martínez, O. G. (2010). Gametófitos y esporófitos jóvenes de cuatro especies de helechos del género Pteris (Pteridaceae) naturalizadas en América. Revista de Biología Tropical 58: 89-102.

Martínez, O. G. (2011). Morfología y distribución del complejo Pteris cretica L. (Pteridaceae) para el continente americano. Candollea 66: 159-180.

Martínez, O. G. \& Prado, J. (2016). Pteris. En M. Ponce, M. D. Arana (Coords.), Flora Vascular de la República Argentina, Vol. 2, Licofitas. Helechos. Gymnospermae. F.O. Zuloaga, M.J. Belgrano. (Eds.), Flora Argentina 2 (pp. 321-329). Buenos Aires: Editorial del Instituto Darwinion.

Martínez, G. A., Arana, M. D., Oggero, A. J. \& Natale, E. S. (2017). Biogeographical relationships and new regionalization of high altitude grasslands and woodlands of the central Pampean ranges (Argentina), based on vascular plants and vertebrates. Australian Systematic Botany 29 (6): 473-488. doi: dx.doi.org/10.1071/ SB16046.

Mazumdar, J. \& Arana, M. D. (2016). Typification of the name Pteris multifida (Pteridaceae subfamily Pteridoideae). Phytotaxa 261: 199-200.

McNeely, J. A. (2001). An introduction to human dimensions of invasive alien species. In: J. A. McNeely (Ed.), The great reshuffling: human dimensions of invasive alien species (pp. 5-20). Cambridge: IUCN.

Nauman, C. E. (1993). Pteris L. En N. R. Morin, (Ed.), Flora of North America 2 (pp. 132-135). Reino Unido: Oxford University Press. 
Oggero, A. J. \& Arana, M. D. (2012). Inventario de la Biodiversidad de Plantas Vasculares del sur de la zona serrana de Córdoba, Argentina. Hoehnea 39 (2): 169- 197.

PPG (Pteridophyte Phylogeny Group) I. (2016). A community-derived classification for extant lycophytes and ferns. Fournal of Systematics and Evolution 54: 563-603.

Prado, J. \& Windisch, P. G. (2000). The genus Pteris L. (Pteridaceae) in Brazil. Boletim do Instituto de Botânica (São Paulo) 13: 103-199.

Robinson, R., Sheffield, E. \& Sharpe, J. M. (2010). Problem ferns: their impact and management. En: K. Mehltreter, L. R. Walker y J. M. Sharpe (Eds.), Fern Ecology (pp. 255-322). Cambridge: Cambridge University Press.

Rumsey, F. \& Crouch, H. J. (2008). Brake out! Pteris go wild in the British Isles. Pteridologist 5: 31-35.

Schuettpelz, E., Schneider, H., Huiet, L., Windham, M.D. \& Pryer, K.M. (2007). A molecular phylogeny of the fern family Pteridaceae: Assessing overall relationships and the affinities of previously unsampled genera. Molecular Phylogenetics E Evolution 44: 1172-1185.

Shieh, W. C. (1966). A synopsis of the fern genus Pteris in Japan, Ryukyu, and Taiwan. Botanical Magazine 79: 283-292.

Silva Junior, W. R., Fernandes, R. S. \& Ferreira, A. W. C. (2018). First record of the exotic fern Pteris tripartita Sw. (Pteridaceae) for the Maranhão state, northeastern Brazil. Biodiversity International Fournal 2 (2): 161-163.

Tryon, R. M. \& Tryon, A. F. (1982). Ferns and allied plants, with special reference to Tropical America. Vol. I-V. Berlin: Springer-Verlag.

Tryon, R. M., Tryon, A. F. \& Kramer, K. U. (1990). Pteridaceae. En K.U. Kramer, \& P.S. Green (Eds.), The Families and Genera of Vascular Plants 1: Pteridophytes and Gymnosperms (pp. 230-256). Berlin: Springer-Verlag.

Walker, T. G. (1970). Species of Pteris commonly in cultivation. British Fern Gazette 10: 143-151.

Wilkins, C. \& Salter, L. (2003). Arsenic hyper-accumulation in ferns: a review. Bulletin Royal Society of Chemistry: 8-10.

Yañez, A., Gutiérrez, D. G. \& Ponce, M. M. (2020). Weedy ferns (Polypodiopsida) in Argentina: diversity, distribution and impact on human activities and ecosystems. Anais da Academia Brasileira de Ciências 92 (1): e20180983. doi 10.1590/0001-3765202020180983

Zhang, G. M., Liao, W. B., Ding, M. Y., Lin, Y. X., Wu, Z. H., Zhang, X. C., Dong, S. Y., Prado, J., Gilbert, M. G., Yatskievych, G., Ranker, T. A., Hooper, E. A., Alverson, E. R., Metzgar, J.S., Funston, A. M., Masuyama, S. \& Kato, M. (2013). Pteridaceae. En Z.Y. Wu, P.H. Raven, D.Y. Hong (Eds.), Flora of China, Vol. 23 (Pteridophytes), (pp. 169-256). Science Press, Beijing \& Missouri Botanical Garden Press, St Louis.

Zhang, L., Rothfels, C. J., Ebihara, A., Schuettpelz, E., Le Péchon, T., Kamau, P., He, H., Zhou, X-M., Prado, J., Field, A., Yatskievych, G., Gao, X. F. \& Zhang, L. B. (2014). A global plastid phylogeny of the brake fern genus Pteris (Pteridaceae) and related genera in the Pteridoideae. Cladistics 31: 1-18. 